\title{
GADAMER'S HERMENEUTICS AS A MODEL FOR THE FEMINIST STANDPOINT THEORY ${ }^{1}$
}

\author{
İsmail Demirezen \\ Doç. Dr. İstanbul Üniversitesi İlahiyat Fakültesi Din Sosyolojisi Anabilim Dalı \\ Associate Professor, Istanbul University Faculty of Theology Department of Sociology of \\ Religion \\ Istanbul, Turkey \\ demirezen@istanbul.edu.tr \\ orcid.org/0000-0001-7141-9114
}

\begin{abstract}
This work which reconstructs Gadamer's hermeneutics for guiding feminist standpoint theory consists of five chapters. Firstly, several possible feminist standpoint theories and their difficulties in addressing how knowledge is situated yet true are clarified. Secondly, it will be examined that Gadamer's proposal for the relevance of the historicity on the reaching to truth. Thirdly, we will discuss Gadamer's notion of fusion of horizons as a way to reach to truth. Fourthly, we will elaborate Wasterling's critique against Gadamer and some arguments that Gadamer's hermeneutics substitutes feminist epistemology for masculine epistemology. Finally, this paper will evaluate Gadamer's proposal for hermeneutics is appropriate for feminist standpoint theory, if so, how it is appropriate.
\end{abstract}

Keywords: Sociology, Feminist Standpoint Theory, Hans-George Gadamer, Feminism, Knowledge.

\section{Feminist Bakış Açısı Kuramına Bir Model Olarak Gadamer Hermenötiği \\ Öz}

Feminist bakış açısı kuramı için bir rehber olarak Gadamer hermenötiğini yeniden yapılandıran bu çalışma beş bölümden oluşmaktadır. İlk olarak, birkaç feminist bakış açısı kuramı ve bilginin hem konumsal hem de hakikat olması konusunu ele almadaki başarısızlıkları incelenecektir. İkinci olarak, Gadamer'in önerisi olarak hakikata ulaşmadaki tarihselliğin etkisi incelenecektir. Üçüncü olarak, hakikate ulaşmada bir yol olarak Gadamer'in kavramı 'ufukların kaynaşması' tartışılacaktır. Dördüncü olarak, Wasterling'in Gadamer'e getirdiği eleştirilere ve Gadamer'in maskulen epistemolojinin yerine feminist epistemolojiyi ikame ettiği iddialarına açıklık getirilecektir. Son olarak, Gadamer'in önerdiği hermenötiğin feminist bakış açısı kuramı için uygun olup olmadığı, uygun ise nasıl uygun olduğu değerlendirilecektir.

Anahtar Kelimeler: Sosyoloji, Feminist Bakış Açısı Kuramı, Hans-George Gadamer, Feminizm, Bilgi.

\footnotetext{
${ }^{1} \mathrm{Bu}$ makale, the American Sociological Association'ın 100. Yillık Toplantısında sözlü olarak sunulan ve basilmayan "Gadamer's Hermeneutics as a Model for the Feminist Standpoint Theory" adlı tebliğin içeriği geliştirilerek ve kısmen değiştirilerek üretilmiş halidir. This paper is the final version of an earlier announcement called "Gadamer's Hermeneutics as a Model for the Feminist Standpoint Theory", not previously printed, but orally presented at a symposium called "100. Annual Meeting of the American Sosiological Association", the content of which has now been developed and partially changed.
} 


\section{INTRODUCTION}

Nancy C.M. Hartsock has argued that women's lives provide a privileged standpoint to criticize male supremacy, patriarchal institutions, and ideology of capitalistic form of patriarchy like the lives of proletarians constitute a standpoint to criticize the exploitation of workers by the capitalist system. ${ }^{2}$ These statements have been the first clues about Hartsock's epistemological and methodological project named the feminist standpoint. In this project, her aim appears to describe feminist truth claims and to offer a methodological ways to validate those claims. ${ }^{3}$ Depending on Marx's standpoint theory of proletarians, she has tried to develop a women's privileged standpoint. ${ }^{4}$

Many other feminist theorists have made contribution to this project. We can accept Sergio Sismendo ${ }^{5}$, Dorothy Smith ${ }^{6}$ and Patricia Hill Collins ${ }^{7}$ as important authors who contribute to the feminist standpoint theory. Although Sismendo tries to apply standpoint theory to science and technology, the basis of this theory exists in the sociological theory of Smith. Collins has developed a black feminist standpoint theory. However, these contributions not only support the theory but also in some parts challenge the theory. For example, black feminist standpoint has made the problem of difference more recognizable.

In addition to the problem of difference, some other developments such as postmodernism and poststructuralism have challenged the theory. These developments have questioned the privilege of the women's standpoint. They lead us rethink what the relevant issues that emerge on how it is possible to produce knowledge from somewhere yet true and second, how it is possible to acknowledge difference with the possibility of critique. ${ }^{8}$ These are the questions which again call for reflection and, therefore, are the question this essay pursues.

\footnotetext{
${ }^{2}$ Nancy C. M. Hartsock, "The Feminist Standpoint: Developing the Ground for a Specifically Feminist Historical Materialism", the Feminist Standpoint Theory Reader: Intellectual and Political Controversies, ed. Sandra G. Harding (London. Routledge, 2004), 36.

${ }^{3}$ Susan Hekman, "Truth and Method: Feminist Standpoint Theory Revisited", Signs 22/2 (Winter 1997): 341.

${ }^{4}$ Hekman, "Truth and Method: Feminist Standpoint Theory Revisited", 341.

${ }^{5}$ Sergio Sismondo, "The Scientific Domains of Feminist Standpoints", Perspective on Science 3/1 (1995): 49-65.

${ }^{6}$ Dorothy Smith, The Everyday World As Problematic, (Georgia: Northeastern University Press, 1987).

7 Patricia Hill Collins, Black Feminist Thought, (New York: Routledge, 2000).

${ }^{8}$ Hekman, "Truth and Method: Feminist Standpoint Theory Revisited", 342.
} 
The call has not gone unheeded. By addressing these issues, several feminist theorists assist in the task of definition of relevant issues that emerge on the possibility of standpoint theory recognizing the problem of difference and postmodern conditions. Nancy Hartsock herself has recognized these issues and has tried to address to them. She admits these problems with her argument because it subsumed feminist of color under the category of white feminist and lesbian under the category of straight, "just as women have been subsumed under the category of man." 9 Then, she wants to diversify the idea while maintaining the utility of standpoint as an apparatus of struggle against dominant groups. ${ }^{10}$

This attitude accepts that there are many different perspectives in the feminist standpoint. However, it falls short in explaining why women's unique point is privileged. These shortcomings lead us to suggest that rather than seeking privilege position, seeking to "derive agency from the very power regimes that constitutes us"11 can overcome not only the problem of difference but also postmodernist and poststructuralist nihilism. In order to derive this kind of agency, standpoint theory needs to find an unfixed ground. It not only acknowledges that knowledge is from somewhere or situated, but also accepts that somewhere is not fixed thing. This approach escapes not only from the modernist idea of transcendental subject by accepting knowledge is situated but also Postmodern nihilism by arguing that knowledge is somewhere but this somewhere is not fixed. ${ }^{12}$ It would be much preferable to find a way to provide this unfixed ground. Is such a perspective possible?

I believe it is. The basis for this perspective is suggested by HansGeorg Gadamer in his work, Truth and Method (1998). ${ }^{13}$ Gadamer describes how understanding is possible, which may be called ontological hermeneutics. He is also concerned with how to reconcile commitments to truth with the condition of diversity and difference. Therefore, I will focus

\footnotetext{
9 Nancy C.M Hartsock, "The Feminist Standpoint Revisited", The Socialist Feminist Project: A Contemporary Reader in Theory and Politics, ed. Nancy Holmstrom (Michigan: Monthly Review Press, 2002), 352.

${ }^{10}$ Hartsock, "The Feminist Standpoint Revisited", 353.

${ }^{11}$ Hekman, "The Ontology and Change: Gadamer and Feminism", Feminist Interpretations of Hans-Georg Gadamer, ed. Lorraine Code (Pennsylvania: The Pennsylvania State University Press, 2003), 199.

${ }^{12}$ Hekman, "The Ontology and Change: Gadamer and Feminism", 191.

${ }^{13}$ Hans-George Gadamer, Truth and Method, trans. Joel Weins Heimer and Donald G. Marshall (Newyork: Continuum, 1998).
} 
on ontological character of hermeneutics suggested by Gadamer. I will attempt a systematic reconstruction of Gadamer's hermeneutics for guiding a feminist standpoint theory.

This work which reconstructs Gadamer's hermeneutics for guiding feminist standpoint theory consists of five chapters. Firstly, several possible feminist standpoint theories and their difficulties in addressing how knowledge is situated yet true are clarified. Secondly, it will be examined that Gadamer's proposal for the relevance of the historicity on the reaching to truth. Thirdly, we will discuss Gadamer's notion of fusion of horizons as a way to reach to truth. Fourthly, we will elaborate Wasterling's critique against Gadamer and some arguments that Gadamer's hermeneutics substitutes feminist epistemology for masculine epistemology. Finally, this paper will evaluate Gadamer's proposal for hermeneutics is appropriate for feminist standpoint theory, if so, how it is appropriate.

\section{FEMINIST STANDPOINT THEORIES}

Before attempting to focus on ontological hermeneutics suggested by Gadamer, it is necessary to briefly discuss feminist standpoint theories which Hartsock, Smith and Sismondo suggest and their difficulties in addressing how knowledge is situated yet true. By examining these theories, chapter one tries to focus on illustrating the importance of these theories in feminist project and their failure in responding to the problem of difference and postmodernist critiques. Thus, the chapter not only explains the features of some feminist standpoint theories to ground the discussion of Gadamer's ontological hermeneutics as a model for feminist standpoint theory, but also presents the relevant issues that emerge on how knowledge may be situated yet true and second, how we can acknowledge difference.

Susan Hekman tells us the basic aspects of several versions of standpoint epistemology. For her, there are two assumptions it rests on: (1) all knowledge is from somewhere or standpoint and (2) feminist standpoint is privileged. ${ }^{14}$

The Marxian notion of a standpoint of proletariat is a good example for not only the notion of standpoint but also belief in the privileges of some standpoints. For Marx, human labor includes ontological features. People are what they do, not what they think. This ontological premises of human labor led Marx to argue that capitalist society produces the "dual vision in

\footnotetext{
${ }^{14}$ Hekman, "Truth and Method: Feminist Standpoint Theory Revisited", 349.
} 
the form of ruling class vision and the understanding available to the ruled." 15

Then, depending on the claim of Marxist epistemology, Hartsock has tried to develop a feminist standpoint theory. For her, the feminist standpoint is similar to the proletarian standpoint in terms of their experiences and activities. ${ }^{16}$ Why do women's activities differ from men's and provide women with a standpoint? The answer for this question constitutes the main bases of her project named feminist standpoint theory. For her, the sexual division of labor makes the feminist standpoint possible. For her, women's activities differ from men's in "double aspect-their contribution to subsistence, and their contribution to childrearing."17

In terms of women's contribution to childrearing and childbearing, for Hartsock, women get very different experience than men. This different experience gives them some advantageous perspectives. For Hartsock, the woman's experience of pregnancy provides them with a unity with nature which is deeper than the proletarian experience of interchange with nature.18 On the other hand, women's motherhood experience provides a unity of mind and body deeper than the worker's labor activity. ${ }^{19}$ Thus, for her, women's lives differ structurally from those of men.

For her, this structural difference between men's and women's lives provides a standpoint. Then, she concludes that women's life experiences provide the ground for an especially feminist materialism and a feminist standpoint to criticize "phallocratic ideology and institutions." 20

In her later works, she pays attentions to diversity among women. She also embraces the situatedness of knowledge which Donna Harraway theorized. For her, knowledges are located in a specific time and space.

\footnotetext{
${ }^{15}$ Hartsock, "The Feminist Standpoint: Developing the Ground for a Specifically Feminist Historical Materialism", 38.

${ }^{16}$ Hartsock, "The Feminist Standpoint: Developing the Ground for a Specifically Feminist Historical Materialism", 41.

${ }^{17}$ Hartsock, "The Feminist Standpoint: Toward a Specifically Feminist Historical Materialism", Feminist Theory Reader: Local and Global Perspectives, ed. Carole R. McCann and Seung-Kyung Kim (London: Routledge, 2017), 371.

${ }^{18}$ Hartsock, "The Feminist Standpoint: Toward a Specifically Feminist Historical Materialism", 373.

${ }^{19}$ Hartsock, "The Feminist Standpoint: Developing the Ground for a Specifically Feminist Historical Materialism", 44.

${ }^{20}$ Hartsock, "The Feminist Standpoint: Developing the Ground for a Specifically Feminist Historical Materialism", 50.
} 
They are therefore situated, the knowledges of specific cultures and people. ${ }^{21}$ Furthermore, for her, "they are both critical of and vulnerable to the dominant culture, both separated off and opposed to it yet contained within it."22

Especially with the last statement, she wants to accept that standpoint knowledge are the situated, but, as Hekman argues, she does not want to embrace the logical consequence of her position: that no situated knowledge is epistemologically privileged. ${ }^{23}$ However, I argue that Gadamer's ontological hermeneutics provides us with an unfixed ground by which we can formulate knowledge as situated and changing.

When Gadamer rejects the objectivism suggested by Enlightenment and emphasizes the crucial role of prejudices in the process of understanding, Gadamer has tried to demonstrate that it is impossible to approach any object from "an unprejudiced, unconditioned, utterly natural standpoint" and therefore, all knowledge is interpreted knowledge. ${ }^{24}$ This perspective necessitates to accept that any truth is not absolute but interpreted one and, therefore, it is situated. Situated knowledge must be from somewhere depending on prejudices. This somewhere constitutes an unfixed ground the feminist standpoint needs. However, this ground is not a subjectivist ground as well.

By paying attention to the temporality of horizons and introducing fusion of horizons as an ongoing process, he does not accept understanding as a subjectivist perspective. ${ }^{25}$ "Gadamer makes this antisubjectivist point when he claims that we only imagine horizons to exist apart from their fusions." 26

Although prejudices provide a ground which is not subjectivist, the ongoing fusion of horizons introduced by Gadamer plays more important role in accepting that it is an unfixed ground. For Gadamer, "understanding is always the fusion of there horizons supposedly existing by themselves. In

\footnotetext{
${ }^{21}$ Hartsock, "Theoretical Bases for Coalition Building: An Assessment of Postmodernism", Feminism and Social Change: Bridging Theory and Practice, ed. Heidi Gottfried (Illinoi: University of Illinois Press, 1996), 270.

${ }^{22}$ Hartsock, "Theoretical Bases for Coalition Building: An Assessment of Postmodernism", 270.

${ }^{23}$ Hekman, "Truth and Method: Feminist Standpoint Theory Revisited", 351.

24 David Detmer, "Gadamer's Critique of the Enlightenment", The Philosophy of Hans-Georg Gadamer, ed. Lewis Edwin Hahn(Chicago: Open Court, 1997), 281.

${ }^{25}$ Bjorn T. Ramberg, "The Source of the Subjective", The Philosophy of Hans-Georg Gadamer, ed. Lewis Edwin Hahn (Chicago: Open Court, 1997), 462.

${ }^{26}$ Ramberg, "The Source of the Subjective", 464.
} 
truth, the horizon of present is grasped in the continuous formation insofar as we must constantly test all our prejudices." 27

The ontological hermeneutics suggested by Gadamer helps us to understand and evaluate Dorothy Smith's theory of feminist standpoint as well. For her, patriarchy represents "this characteristic relation of power among women and men, in which direct and personal relations are organized and determined by an impersonal apparatus." 28 Furthermore, she argues that the standpoint of women plays a role to negate "the ideological forms from which their experience as subjects has been excluded." 29

She emphasizes experience which women get in their everyday life. For her, women's experience "gives access to a knowledge of what is tacit, known in the doing, and often not yet discursively appropriated." 30 For her, because it is not discursively constructed, it is superior to the abstract knowledge produced by sociologists. For her, the abstract knowledge of the sociologist has been shaped by power relations and patriarchy.

Although she is right in terms of taking women's experience as a starting point and a ground, how can anybody assert that this experience is authentic and void of power relations? If we talk in Gadamerian terminology, women's own experience can be taken as starting prejudices which inform us about patriarchy but we have to test our prejudices because they may be incorrect prejudices. In the process of testing these prejudices, may be we move another horizon. These ongoing fusions of horizons remind us that this ground is not fixed but changeable.

Finally, we can look at Sergio Sismendo's standpoint theory. She tries to define "relatively narrow ground for the relevance of standpoint theory to science and technology: namely, the oppressed are in a potentially good position to understand social relations." 31 For her, feminist perspective provides new insights not only in social sciences such as sociology and psychology but also in natural sciences such biology and mathematics. For her, feminist perspective or masculine perspective influence the problem choices, subject matter and norms of behavior." 32 Thus, for her, to accept the

\footnotetext{
27 Gadamer, Truth and Method, 210.

28 Smith, The Everyday World As Problematic, 97.

${ }^{29}$ Smith, The Everyday World As Problematic, 97.

30 Smith, "Comment on Hekman's Truth and Method: Feminist Standpoint Theory Revisited", Signs 22/2 (Winter: 1997): 395.

${ }^{31}$ Sismondo, "The Scientific Domains of Feminist Standpoints", 49.

32 Sismondo, "The Scientific Domains of Feminist Standpoints", 62.
} 
arguments for a standpoint theory leads scientists to recognize the applicability of standpoint theory to science.

However, who will decide the relevance of standpoint theory to science and technology? Although the feminist standpoint theory helps us to recognize gender-related issues, it, in a sense, helps us to conceal other power relations in the science also. These points lead us to suggest that the feminist standpoint as a starting prejudice helps us to recognize the social picture of science, and gender-related issues. However, we cannot argue that these prejudices are absolute and correct. They need also to be tested.

\section{ONTOLOGICAL HERMENEUTICS}

After noticing several possible feminist standpoint theories and their difficulties in addressing how knowledge can be situated yet true, it is time to return to Gadamer's proposal for the relevance of the historicity on reaching to truth in order to understand whether or not it is possible to reach absolute truth. Indeed, we have earlier mentioned this briefly. However, we will discuss his proposal here more widely in order to understand his ontological character of hermeneutics.

Gadamer, in favor of ontology of human understanding, is interested in how understanding is possible. For Gadamer, hermeneutics does not aim to provide directions for understanding, but "to lay bare the ontological structure of the process of understanding." ${ }^{33} \mathrm{His}$ goal is to clarify the ontological conditions in which understanding occurs.

For Gadamer, to overcome the ontological conditions named by Heideger as being thrown is impossible because the ontological conditions of understanding are always already positioned in a world before beginning to criticize prejudgments. "Reason is not something that can ever exist independently of history, and of specific customs and traditions, rather it is always conditioned by them even when it is most critical of them." 34

Enlightenment perspective about understanding that requests us to overcome our present prejudices is only on the hypothesis that our own historicity and our prejudices are an accidental issues. However, if they are an ontological rather than a merely accidental and subjective, then our own

\footnotetext{
${ }^{33}$ Heinz Kimmerle, "Hermeneutical Theory or Ontological Hermeneutics", Journal for Theology and the Church, 4 (1967): 113.

34 Detmer, "Gadamer's Critique of the Enlightenment", 280.
} 
present prejudices are already involved in any act of understanding. ${ }^{35}$ As Linge argues that "to be historical, for Gadamer, means not to be absorbed into self knowledge." 36

Gadamer considers historicity as ontological. If there is no Archimedean vantage point from which the reason can overcome historicity, and prejudices are no longer negative issues but rather the positive ground, the truth we seem to reach at the end of the experience of understanding is not absolute truth. If we cannot reach absolute truth, it is clear that every knowledge is situated one. If every knowledge is situated, how can it be true also? Is there any ground we can depend on? How can we avoid of subjectivism? Gadamer offers the notion "fusion of horizons" as a response not only to objectivism but also to subjectivism. Therefore, it is necessary to examine it.

\section{THE FUSION OF HORIZONS}

For Gadamer, the notion of horizon is important to emphasize the influences of historical consciousness. For him, the notion of horizon is "the range of vision that includes everything that can be seen from a particular vantage point." ${ }^{37}$ For him, understanding is a kind of fusion of horizons. Gadamer calls for a "fusion of horizons:" 38

In fact, the horizon of present is continually in the process of being formed because we are continually having to test all our prejudices. An important part of this testing occurs in encountering the past and in the understanding the tradition from which we come. Hence, the horizon of present cannot be formed without the past. There is no more an isolated horizon of the present in itself than there are historical horizons which have to be acquired. Rather understanding is always the fusion of horizons supposedly existing by themselves.

For Gadamer, the process of understanding includes the tension between the other and the horizon of present. To overcome with this tension, it is necessary to "project an historical horizon that is different from the horizon of the present." 39 However, in the experience of understanding,

\footnotetext{
${ }^{35}$ David Linge, E. "Dilthey and Gadamer: Two Theories of Historical Understanding", Journal of the American Academy of Religion, 41/4 (December 1973): 547.

${ }^{36}$ Linge, "Dilthey and Gadamer: Two Theories of Historical Understanding", 547.

37 Gadamer, Truth and Method, 302.

38 Gadamer, Truth and Method, 305.

${ }^{39}$ Gadamer, Truth and Method, 305.
} 
"it does not became solidified into the self-alienation of a past consciousness, but is overtaken by our own present horizon of understanding." 40 Furthermore, for Gadamer, "understanding always involves something like applying the text to be understood to the interpreter's present situation." ${ }^{41}$; namely, interpretation always implies a relating of the symbol to the interpreter's own situation. As we see, he does not separate application from understanding and interpretation; furthermore, he accepts them as one unified process.

From this perspective, he approaches the problem of application and he suggest that understanding is always application. With this statement, he implies that fusion of horizons "serves applicable meaning, in that it explicitly and consciously bridges the temporal distance that separates the interpreter from the text and overcomes the alienation of meaning that the text has undergone." 42

Feminist standpoint theory suggests that feminist perspective has own position that differentiates it from other perspective in the power regimes that constitute us. This suggestion implies that the member must have a kind of the pre-understanding or presuppositions about power regimes because understanding something without presuppositions is impossible. However, that feminist standpoint theory accepts its perspective also is situated requests the member of feminist standpoint to open herself to other perspectives in order to get more correct understanding in power regime and drive agency in the power regimes constitute us. This request can be translated to the Gadamerian terminology as testing the prejudices. As Gadamer tries to clarify the ontological conditions of understanding, he emphasizes testing pre-understanding in order to differentiate the legitimate prejudice from false pre-understandings. However, at the end of the process of understanding, neither the new horizon of the partners is completely different from their past horizons, nor it is conversion, but rather it is the fusion of horizons. This does not mean there are "horizons to exist apart from their fusion; the fusion, the encounter, is not what expresses or transmits meaning, it is not synthesis of separable components of meaning, it is literally what constitutes it." 43 It follows from these considerations that fusion of two historical horizons, can never produce a genuine unity; the

\footnotetext{
40 Gadamer, Truth and Method, 306.

${ }^{41}$ Gadamer, Truth and Method, 308.

42 Gadamer, Truth and Method, 311.

${ }^{43}$ Ramberg, "The Source of the Subjective", 464.
} 
result of the fusion is neither the disappearance of my horizon into "other's" nor of his horizon into mine. The only possibility is that a fusion of horizons results in the production of a third horizon, as defined by my interpretation of the other. 44

\section{FEMINIST APPROACHES TO GADAMER'S HERMENEUTICS}

The previous discussion is meant as a clarification of Gadamer's hermeneutics rather than as a justification for it. If this clarification is successful, then certain neglected dimensions of Gadamer's hermeneutics will have to be considered in the relevance of his hermeneutics to feminist standpoint theory.

In the course of an essay on this topic, "Postmodern Hermenutics? Toward a Criritical Hermenutics" Veronica Vasterling criticizes Gadamer for asserting that prejudices of the tradition are inescapable. Vasterling's analysis shows that as long as the tradition plays a decisive role in our understanding, it leads one to disregard power relations. For her, "in view of the power struggles involved, it might be more correct to describe tradition as the story of the winners, a story that gains authority because the memory of the dissenters, the silenced, the losers is forgotten and erased. She continues: "if, according to Gadamer, tradition always mediates truth in which one must try to share, the question arises whether truth is another, respectable name of power or success." 45 However, we agree with SusanJudith Hoffmann in her claim that "Gadamer's work is a perfect example of what some feminists claim needs to be done" because his hermeneutics emphasizes our finitude nature, our reliance on tradition, historical effects on us and how to break with tradition." 46 As we said earlier, Gadamer suggests an ongoing fusion of horizons. The notion of fusion of horizons provides us with the ability to rehabilitate the authority of tradition, namely, to derive agency in the power regimes.

In her essay, Gadamer's Feminist Epistemology, Linda Martin Alcoff argues that "the openness to alterity, the move from knowledge to

\footnotetext{
${ }^{44}$ Stanley Rosen, "Horizontvershmelzung", The Philosophy of Hans-Georg Gadamer, ed. Lewis Edwin Hahn (Chicago: Open Court, 1997), 213.

${ }^{45}$ Veronica Vasterling, "Postmodern Hermeneutics? Toward a Critical Hermeneutics", Feminist Interpretations of Hans-Georg Gadamer, ed. Lorraine Code (Pennsylvania: The Pennsylvania State University Press, 2003), 168.

46 Susan-Judith Hoffmann, "Gadamer's Philosophical Hermeneutics and Feminist Projects", Feminist Interpretations of Hans-Georg Gadamer, ed. Lorraine Code (Pennsylvania: The Pennsylvania State University Press, 2003), 86.
} 
understanding, holism in justification, and immanent realism" are in accord with feminist tendencies. For her, these features of Gadamer's philosophical hermeneutics "may seem to make Gadamer out to be more feminine than feminist." 47 Although she looks at these features from positive perspective, we argue that this perspective substitutes "a feminist epistemology for the masculinist epistemology of the Enlightenment." Furthermore, it substitutes "a universal model of truth (a feminist epistemology) in place of masculinist model that the Enlightenment proclaimed to be the unique source of truth." 48

However, I agree with Hekman in that to claim that "this contextual feminine understanding is superior to the abstract, rationalist masculine model" is a kind of falling in the trap of universalizations and reductive metanarratives. Even arguing that feminist epistemology is absolute "entails that feminists are attempting to substitute another absolute, feminist epistemology, for masculine epistemology." 49 Rather than supporting the dichotomies of Enlightenment thought about feminine or masculine epistemologies, we need to reject these dichotomies. If these dichotomies were rejected, "their gendered connotations would also be displaced."50

\section{CONCLUSION}

Our discussion of Gadamer's hermeneutics for feminist standpoint theory has begun with asserting the failure of several theories in addressing how knowledge is situated yet true. We have argued that Hartsock, Smith and Sismondo's feminist standpoint theories have several difficulties to addressing how knowledge is situated yet true. Although they accept that knowledge is situated but they do not want to embrace the logical consequence of this position: no knowledge is privileged.

We have also elaborated on Gadamer's proposal for historical effect on the reaching to truth in order to understand his notion of fusion of horizons. We have suggested that historical effect, Gadamer believes, is not a negative element to understand Other, because the preunderstandings of tradition give an opportunity to start the process of understanding. This

\footnotetext{
${ }^{47}$ Linda Martin Alcoff, "Gadamer's Feminist Epistemology", Feminist Interpretations of HansGeorg Gadamer, ed. Lorraine Code (Pennsylvania: The Pennsylvania State University Press, 2003), 233.

48 Hekman, Gender and Knowledge Elements of a Postmodern Feminism (Boston: Northeastern University Press, 1990), 16.

${ }^{49}$ Hekman, Gender and Knowledge Elements of a Postmodern Feminism, 17.

${ }^{50}$ Hekman, Gender and Knowledge Elements of a Postmodern Feminism, 17.
} 
provides us with a ground in order to derive an agency from the regimes of truth which constitute us. However, Gadamer's hermeneutics urges us to test our ground, prejudices. This process of testing preunderstandings of tradition continues until achieving the satisfactory knowledge. If this is true, this gives us the second suggestion: knowledge and truth of reality are dynamic, namely an unfixed ground.

In addition, we have tried to examine what conditions of understanding are. In this point, Gadamer's notion of fusion of horizons has become crucial. In Gadamer's view, every understanding is a kind of fusion of horizons. This approach seems to suggest that we recognize the contingency of our knowledge. Rather than denying the differences, the approach pays attention to the differences. This gives us the third suggestion: feminist perspective is present in more than one standpoint.

However, these reflections on Gadamer's hermeneutics lead us give ear to the voice of some issues expressed by some feminist theorists. First, Vasterling criticizes Gadamer for asserting that the preunderstandings of traditions play an effective role in the process of understanding, and this effective role can prelude the knower to recognize the ideology of the tradition. However, Gadamer's hermeneutics suggests one to test her prejudice. In the process of testing, she can recognize her illegitimate prejudice and therefore, the ideology of tradition.

Gadamer's approach has been accepted as substituting a feminist epistemology for the masculinist epistemology of the Enlightenment. However, as we said earlier, Gadamer's hermeneutics rejects the dichotomies of Enlightenment: abstract vs contextual knowledge. Therefore, it is nonsense to argue that Gadamer substitutes a feminist epistemology for the masculine epistemology.

To summarize, although it is not a final answer for the feminist standpoint, Gadamer's hermeneutics gives us some clues for understanding some difficulties in the feminist standpoint theory and some solutions for them. As long as the feminist standpoint theory continues, our present horizon will stay open to new standpoints, and new perspectives to uncover the masculine institutions and ideology.

\section{BIBLIOGRAPHY}

Alcoff, Linda Martin. "Gadamer's Feminist Epistemology". Feminist Interpretations of Hans-Georg Gadamer. Ed. Lorraine Code. 231-259. Pennsylvania: The Pennsylvania State University Press, 2003. 
Collins, Patricia Hill. Black Feminist Thought. New York: Routledge, 2000.

Detmer David. "Gadamer's Critique of the Enlightenment". The Philosophy of Hans-Georg Gadamer. Ed. Lewis Edwin Hahn. 275-287. Chicago: Open Court, 1997.

Gadamer, Hans-George. Truth and Method. Trans. Joel Weins Heimer and Donald G. Marshall. Newyork: Continuum, 1998.

Hartsock, Nancy C.M. "Theoretical Bases for Coalition Building: An Assessment of Postmodernism". Feminism and Social Change: Bridging Theory and Practice. Ed. Heidi Gottfried. 256-275. Illinoi: University of Illinois Press, 1996.

Hartsock, Nancy C.M. "The Feminist Standpoint Revisited". The Socialist Feminist Project: A Contemporary Reader in Theory and Politics. Ed. Nancy Holmstrom. 350-360. Michigan: Monthly Review Press, 2002.

Hartsock, Nancy C.M. "The Feminist Standpoint: Developing the Ground for a Specifically Feminist Historical Materialism". The Feminist Standpoint Theory Reader: Intellectual and Political Controversies. Ed. Sandra G. Harding. 35-55. London: Routledge, 2004.

Hartsock, Nancy C.M. “The Feminist Standpoint: Toward a Specifically Feminist Historical Materialism". Feminist Theory Reader: Local and Global Perspectives. Ed. Carole R. McCann, Seung-Kyung Kim. 368-384. London: Routledge, 2017.

Hekman, Susan J. Gender and Knowledge Elements of a Postmodern Feminism. Boston: Northeastern University Press, 1990.

Hekman, Susan J. "Truth and Method: Feminist Standpoint Theory Revisited", Signs 22/2 (1997): 341-365.

Hekman, Susan J. "The Ontology and Change: Gadamer and Feminism". Feminist Interpretations of Hans-Georg Gadamer. 181-203. Ed. Lorraine Code. Pennsylvania: The Pennsylvania State University Press, 2003.

Hoffmann, Susan-Judith. "Gadamer's Philosophical Hermeneutics and Feminist Projects". Feminist Interpretations of Hans-Georg Gadamer. Ed. Lorraine Code. 81-109. Pennsylvania: The Pennsylvania State University Press, 2003.

Kimmerle, Heinz. "Hermeneutical Theory or Ontological Hermeneutics". Journal for Theology and the Church 4 (1967): 107-121.

Linge, David E. "Dilthey and Gadamer: Two Theories of Historical Understanding". Journal of the American Academy of Religion. 41 (DEC. 1973): 536-553.

Ramberg, Bjorn T. "The Source of the Subjective". The Philosophy of Hans-Georg Gadamer. Ed. Lewis Edwin Hahn. 459-472. Chicago: Open Court, 1997.

Rosen, Stanley. "Horizontvershmelzung". The Philosophy of Hans-Georg Gadamer. Ed. Lewis Edwin Hahn. Chicago: Open Court, 1997.

Sismondo, Sergio. "The Scientific Domains of Feminist Standpoints". Perspective on Science 3/1(1995.): 49-65.

Smith, Dorothy. The Everyday World As Problematic. Georgia: Northeastern University Press, 1987.

Smith, Dorothy. "Comment on Hekman's Truth and Method: Feminist Standpoint Theory Revisited." Signs 22/2 (1997): 392-398.

Vasterling, Veronica. "Postmodern Hermeneutics? Toward a Critical Hermeneutics". Feminist Interpretations of Hans-Georg Gadamer. Ed. Lorraine Code. 149-181. Pennsylvania: The Pennsylvania State University Press, 2003 